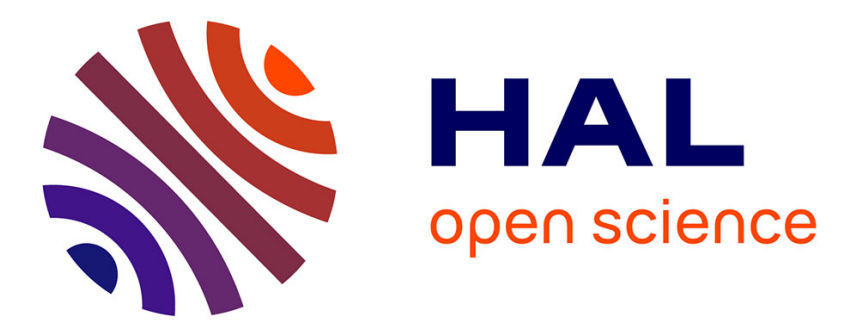

\title{
NADPH-diaphorase activity in the central nervous system of the Gray mussel (Dunker) under stress conditions: A histochemical study
}

\author{
M.A. Vaschenko, E.P. Kotsyuba
}

\section{- To cite this version:}

M.A. Vaschenko, E.P. Kotsyuba. NADPH-diaphorase activity in the central nervous system of the Gray mussel (Dunker) under stress conditions: A histochemical study. Marine Environmental Research, 2008, 66 (2), pp.249. 10.1016/j.marenvres.2008.03.001 . hal-00563030

\section{HAL Id: hal-00563030 \\ https://hal.science/hal-00563030}

Submitted on 4 Feb 2011

HAL is a multi-disciplinary open access archive for the deposit and dissemination of scientific research documents, whether they are published or not. The documents may come from teaching and research institutions in France or abroad, or from public or private research centers.
L'archive ouverte pluridisciplinaire HAL, est destinée au dépôt et à la diffusion de documents scientifiques de niveau recherche, publiés ou non, émanant des établissements d'enseignement et de recherche français ou étrangers, des laboratoires publics ou privés. 


\section{Accepted Manuscript}

NADPH-diaphorase activity in the central nervous system of the Gray mussel

Crenomytilus grayanus (Dunker) under stress conditions: A histochemical study

M.A. Vaschenko, E.P. Kotsyuba

PII:

S0141-1136(08)00108-6

DOI:

10.1016/j.marenvres.2008.03.001

Reference:

MERE 3244

To appear in:

Marine Environmental Research

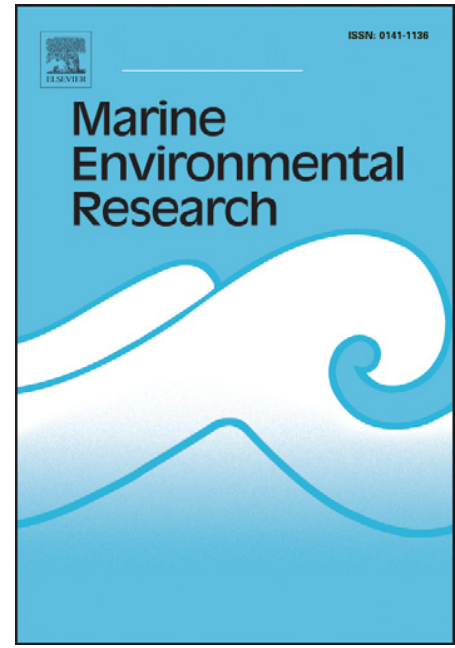

Received Date: 10 August 2005

Revised Date: $\quad 20$ February 2008

Accepted Date: $\quad 2$ March 2008

Please cite this article as: Vaschenko, M.A., Kotsyuba, E.P., NADPH-diaphorase activity in the central nervous system of the Gray mussel Crenomytilus grayanus (Dunker) under stress conditions: A histochemical study, Marine Environmental Research (2008), doi: 10.1016/j.marenvres.2008.03.001

This is a PDF file of an unedited manuscript that has been accepted for publication. As a service to our customers we are providing this early version of the manuscript. The manuscript will undergo copyediting, typesetting, and review of the resulting proof before it is published in its final form. Please note that during the production process errors may be discovered which could affect the content, and all legal disclaimers that apply to the journal pertain. 


\title{
ACCEPTED MANUSCRIPT
}

NADPH-diaphorase activity in the central nervous system of the Gray mussel Crenomytilus grayanus (Dunker) under stress conditions:

A histochemical study

M.A. Vaschenko*, E.P. Kotsyuba

A.V. Zhirmunsky Institute of Marine Biology, Far East Branch of Russian Academy of Sciences, Vladivostok 690041, Russia

\begin{abstract}
NADPH-diaphorase (NADPH-d) is a histochemical marker for nitric oxide synthase (NOS) and is widely used to identify nitric oxide (NO) producing cells in the central nervous system (CNS) of both vertebrates and invertebrates. NADPH-d histochemistry was used to quantitatively characterize putative NO-producing neurons in the CNS of the Gray mussel Crenomytilus grayanus subjected to two kinds of stress, environmental pollution and hypoxia, the latter caused by the mollusk transportation in a small volume of water. Mussels were sampled from one relatively clean (reference) and four polluted sites in Amursky and Ussuriysky Bays (Peter the Great Bay, Sea of Japan) in August, 2003. The number of NADPH-d-positive neurons was estimated and enzyme activity was determined from the optical density of the formazan precipitate in the CNS ganglia at 0,3 , and $72 \mathrm{~h}$ after sampling. Just after sampling, NADPH-d-positive neurons were found in the cerebropleural, visceral, and pedal ganglia. The number and staining intensity of NADPH-dpositive neurons were significantly higher than in the pedal ganglia than the other two ganglia. There were significant differences in the number of NADPH-d-positive neurons and enzyme activity between the mussels from the reference and heavily polluted stations. The proportion and staining intensity of NADPH-d-positive neurons were maximum in the pedal ganglia of the mussels from the heavily polluted station in Amursky Bay. Transportation of mussels in a limited volume of water for $3 \mathrm{~h}$ resulted in a significant increase in the proportion and staining intensity of NADPH-dpositive neurons in all ganglia. In mollusks from all stations kept in aerated aquaria for $72 \mathrm{~h}$, both the proportion and staining intensity of NADPH-d-positive neurons did not differ significantly from the initial level. However, the differences in the proportion and staining intensity of NADPH-dpositive neurons between the reference and heavily polluted stations were significant. The present results suggest that NO is involved in mollusk nerve cell adaptation to environmental changes.
\end{abstract}

\footnotetext{
* Corresponding author: Tel.: +7-4232-311186; fax: +7-4232-310900.

E-mail address: mvaschenko@ mail.ru (M.A. Vaschenko)
} 
Keywords: NO, nitric oxide, NO-synthase, neurons, bivalves, Mytilus edulis, pollution, hypoxia, adaptation

\section{Introduction}

Nitric oxide (NO) is a signaling molecule synthesized from $L$-arginine and $\mathrm{O}_{2}$ by nitricoxide synthase (NOS, EC 1.14.13.39). NOS exists in three distinct isoforms, neuronal (nNOS, type I), endothelial (eNOS, type III), and inducible (iNOS, type II) (sea for review Natha \& Xie, 1994; Mayer \& Hemmens, 1997; Stuehr, 1999; Alderton et al., 2001). nNOS and eNOS are $\mathrm{Ca}^{2+}-$ dependent and are constitutively expressed in nervous and vascular endothelial cells, respectively, whereas iNOS is $\mathrm{Ca}^{2+}$-independent and is induced mainly in macrophages upon stimulation by cytokines and polysaccharides.

In the central nervous system (CNS), NO synthesis requires reduced nicotinamide adenine dinucleotide phosphate (NADPH) as an electron donor. The activity of NADPH-diaphorase (NADPH-d, EC 1.6.99.1), a NADPH-dependent oxido-reductase, was shown to colocalize with nNOS immunostaining (Bredt et al., 1991; Dawson et al., 1991). NADPH-d can also convert tetrazolium salts to insoluble dark blue formazan crystals in the presence of NADPH. NADPH-d. Histochemistry can thus be used to detect specific populations of neurons that use NO as a neuronal messenger molecule. Positive NADPH-d staining has been successfully used as a marker for NOS in the CNS of both vertebrates (Bredt et al., 1991; Hope et al., 1991; Cozzi et al., 1997) and invertebrates, including mollusks (Moroz \& Gillette, 1995; Moroz et al., 1996; Annikova et al., 2000; Newcomb \& Watson, 2001).

In mammals, NO is involved in numerous physiological functions such as regulation of vascular tone, cellular signaling in the brain, and pathogen elimination in nonspecific immune response (for reviews see Moncada et al., 1991; Garthwaite, 1991; Nathan, 1992; Wink \& Mitchell, 1998). In addition, NO functions in a large number of pathophysiological conditions, including numerous degenerative diseases, stroke, and myocardial infarction, have been intensively studied and debated (for reviews see Wink \& Mitchell, 1998; Calabrese et al., 2000). Of special interest is NO role in adaptive responses of an organism to stress conditions. NO production may be altered by a variety of stressors including restraint (Masood et al., 2004), immobilization (Shirakawa et al., 2004), hypoxia (Manukhina et al., 2000), hypo- and hyperthermia (Han et al., 2002; Lee et al., 2005), pain shock (Aley et al., 1998), and physical training (Green et al., 2004; see also a review by Malyshev \& Manukhina, 1998). 
Our knowledge of NO distribution and functions in invertebrates is much less comprehensive. The available data suggest that NO is an evolutionarily ancient signaling molecule occurring in many invertebrate groups and that invertebrates use it in a similar manner as mammals (see for review Colasanti \& Venturini, 1998; Stefano \& Ottaviani, 2002; Palumbo, 2005; Toda \& Ayajiki, 2006). Thus, several studies suggest involvement of NO-signaling in stress reactions in sponges exposed to heat stress (Giovine et al., 2001) and bivalve mollusks exposed to tributyltinoxide (Smith et al., 2000) and hypoxia (Kotsyuba \& Kotsyuba, 2003).

Bivalve mollusks including mussels are widespread in the coastal zone of the World Ocean, including shallow waters where they have to adapt to changes in environmental factors such as temperature, salinity, and oxygen concentration (Bayne, 1976). High metabolic plasticity of mussels promotes their adaptation to changing environment (Berger, Kharazova, 1997; Sukhotin, Portner, 1999; Halpin et al., 2004). Another stress factor influencing mussel physiology is marine environmental pollution (Bayne, 1985). Biochemical, cellular, and physiological responses of sentinel mussels to various contaminants have been intensively studied, and mussels have been widely used as biomarkers for marine pollution monitoring all around the world (Bayne et al., 1979; Moore, 1985; Krishnakumar et al., 1995; Cajaraville et al., 2000; Livingstone et al., 2000; Moles \& Hale, 2003; Narbonne et al., 2005; Moore et al., 2006). An increasing attention has been paid to histo- and cytopathological changes in the mussel digestive gland that is a major site of accumulation, detoxication, and excretion of organic and inorganic contaminants (see for review $\mathrm{Au}, 2004)$. To our knowledge, there is no data on mussel CNS response to environmental pollution.

The present paper deals with histochemical investigation of NADPH-d activity in the CNS of the Gray mussel Crenomytilus grayanus inhabiting polluted and relatively clean areas in Peter the Great Bay (Sea of Japan). The Gray mussel is widespread in the bay, forming dense populations (druses) at 2-20 m depth. It has been widely used as an indicator species for monitoring heavy metal and organochlorine pesticide pollution in the bay (Shulkin \& Kavun, 1995; Tkalin et al., 1997, 1998; Shulkin et al., 2002, 2003; Monirith et al., 2003).

\section{Materials and methods}

\subsection{Sampling strategy}

Mussels were sampled in August 2003 at 5 stations in Amursky and Ussuriysky Bays, secondary bays of Peter the Great Bay (Fig. 1). These bays are separated by Muraviev-Amursky Peninsula, where Vladivostok is located. Vladivostok is the largest port in the Russian Far East of over 600 thousand population. The bays are mainly polluted by industrial and municipal sewage of 
Vladivostok and its suburbs, ports, and sea transport and by runoffs of many influent rivers. Among the latter, Razdolnaya River is the largest. The river enters the northern extremity of Amursky Bay and brings agricultural effluents and untreated sewage from Ussuriysk. Another substantial source of the bays' pollution is a dump near Tokarevsky Cape (close to station 2) and a municipal dump on the Gornostay Bay coast (north from station 4) (Tkalin et al., 1993; Belan et al., 2003). In the former dump, in the early 1980s, sediments excavated from heavily contaminated Zolotoy Rog Bay were discharged into Amursky Bay (Tkalin et al., 1993).

Marine environment monitoring in Amursky and Ussuriysky Bays has been conducted from the middle of the 1970s both within government programs and individual research projects. Based on the results of these studies (see for review Vaschenko, 2000; Vaschenko \& Pitruk, 2001), we concluded that Amursky Bay is polluted to a greater extent than Ussuriysky Bay. For example, average concentrations of metals of anthropogenic origin $(\mathrm{Zn}, \mathrm{Cu}$, and $\mathrm{Pb})$ in surface bottom sediments of Amursky and Ussuriysky Bays were 121 and 60,25 and 15, and 28 and $23 \mu \mathrm{g} / \mathrm{g}$ of dry weight (Tkalin et al., 1996), and DDT content in sediments of the two bays varied between 4.4-14.8 and 4.4-9.1 ng/g of dry weight, respectively (Tkalin, 1996). Sediments form the eastern coastal area of Amursky Bay (from Tokarevsky Cape to the Vtoraya Rechka River mouth) and western coastal area of Ussuriysky Bay (close to the Gornostay Bay dump) are polluted mostly by heavy metals and organochlorine pesticides. The open part of Peter the Great Bay (off Russky, Popov, Reineke and Rikorda Islands) is considered a relatively clean zone. For this reason, station 1 near the western coast of Russky Island was selected as a reference station. Stations 2 and 3 are located in Amursky Bay, near the western coast of Muraviev-Amursky Peninsula. Station 2 is located at Tokarevsky Cape, in the area of the former dumping (the dumping of dredged sediments was terminated here in 1985). Station 3 is located near the mouth of the Vtoraya Rechka River. Stations 4 (Tikhaya Bay) and 5 (Lazurnaya Bay) are located in Ussuriysky Bay, near the eastern coast of Muraviev-Amursky Peninsula, $14 \mathrm{~km}$ southwards and $22 \mathrm{~km}$ northwards of the city dump, respectively.

At each station, 30 mature mussels with a shell length of 10-14 cm were collected at a 3-4 $\mathrm{m}$ depth. Water temperature and salinity at stations $1-5$ were $19.5,20.1,20.6,19.5,19.8{ }^{\circ} \mathrm{C}$ and $33.5,32.9,31.7,33.6,33.2 \%$ o, respectively.

The visceral, cerebropleural, and pedal ganglia of 10 mollusks sampled at every station (except for station 2) were dissected immediately (within $5 \mathrm{~min}$ ) after sampling and fixed in $4 \%$ paraformaldehyde in $0.1 \mathrm{M}$ sodium phosphate buffer $(\mathrm{pH} 7.2)$ at $4^{\circ} \mathrm{C}$ for $2 \mathrm{~h}$. The intact mussels were delivered to the Institute of Marine Biology in a vessel with sea water. To reveal the effect of transportation on NADPH-d activity, ganglia of 10 other mollusks from each station were prepared and fixed as described above $3 \mathrm{~h}$ after sampling. The rest of the animals were placed in aquaria with aerated sea water, and their ganglia were prepared and fixed as described above $72 \mathrm{~h}$ after sampling. 


\subsection{NADPH-diaphorase histochemistry}

NADPH-d was detected in neurons by a routine histochemical technique based on NADPHdependent conversion of nitroblue tetrazolium to insoluble dark blue formazan precipitate (Hope \& Vinsent, 1989). Ganglia fixed as described above were washed in three changes of $15 \%$ sucrose in $0.15 \mathrm{M}$ Tris- $\mathrm{HCl}$ buffer ( $\mathrm{pH} 8.0$ ) at $4^{\circ} \mathrm{C}$ for $12 \mathrm{~h} .30 \mu \mathrm{m}$ cryostat sections were cut and incubated in $0.15 \mathrm{M}$ Tris- $\mathrm{HCl}$ buffer ( $\mathrm{pH}$ 8.0) containing 0.5 mM $\beta$-NADPH (Sigma), $0.5 \mathrm{mM}$ nitroblue tetrazolium (Sigma), and $0.3 \%$ Triton-X100 at $37^{\circ} \mathrm{C}$ for $1 \mathrm{~h}$. Sections incubated in the same media without NADPH were used as control. After incubation, sections were washed in two changes of distilled water, dehydrated through an ethanol series, and mounted.

Observations were made and micrographs were obtained using an Olympus BH2-RFCA microscope. The number of NADPH-d-positive neurons in the visceral, cerebropleural, and pedal ganglia was determined. For each ganglion, NADPH-d-positive neurons were counted in seven sections, and the average number of neurons per section was calculated. The number of NADPH-dpositive neurons was expressed as a percentage of the total number of neurons.

Neuronal NADPH-d activity was estimated using an automatic image analysis system Allegro-MC (Afanasiev et al., 2002). The system was based on an ERMA-2 microscope (Japan) equipped with a CREATIVE videocamera (Japan) and IBM-compatible computer with a video capture card ATI-128 pro (32 MB, 1280×1024 pixel). Seven sections were taken from each ganglion. In each section, the optical density of every NADPH-d-positive neuron was measured in 5 randomly selected fields of vision using VideoTest 5.0 software (VideoTestT Software, St. Petersburg, Russia).

\subsection{Data analysis}

Data are presented as means \pm SEM; differences between right and left ganglia are not significant $(P>0.05)$, therefore quantitative parameters are presented for one ganglion from each ganglion pair (Table 1). Statistical differences were determined by one-way ANOVA followed by Tukey's multiple comparison test for all pairs of groups or Dunnett's multiple comparison test for all groups vs the control group. The data derived from station 2 were analysed by Student's $t$-test for paired data. All tests were performed with GraphPad Prism, version 4.0 for Windows (GraphPad Software, San Diego, CA). 


\section{Results}

The CNS of $C$. grayanus consists of the paired cerebropleural, visceral, and pedal ganglia. NADPH-d histochemistry revealed a small portion of neuron cell bodies and processes in all ganglia. No NADPH-d-positive neurons were revealed in control sections.

\subsection{NADPH-d activity in mussel ganglia just after sampling}

Station 1 (reference station). The maximum number of NADPH-d-positive neurons (about $1.5 \%$ of the total number of neurons) was found in the pedal ganglia. In the cerebropleural and visceral ganglia it was about one-seventh and one-thirtieth of that in the pedal ganglia, respectively (Table 1). Neurons of the pedal ganglia were most intensely stained, and ones of the visceral ganglia were least intensely stained. NADPH-d staining intensity differed significantly between all ganglia pairs (visceral vs pedal and cerebropleural vs pedal, $\mathrm{P}<0.001$; visceral vs cerebropleural, $P<0.05, P<0.01, P<0.001$ ) except for several cases (Table 1 ).

In all ganglia, NADPH-d-positive neurons were comprised of small (3-8 $\mu \mathrm{m})$, medium (10$15 \mu \mathrm{m})$, and large $(20-25 \mu \mathrm{m})$ cells. In the pedal ganglia, NADPH-d-positive neurons formed clusters, the largest of which was found in the dorsomedial portion of the ganglion (Fig. 2A). Large pyriform cells were most intensely stained (0.348-0.968 optical density units). Small and mediumsized neurons, oval, pyriform, or spindle in shape, were scattered among large cells. Their staining intensity varied considerably (0.141-0.744 optical density units). In the interganglion commissure and paracortical areas of the neuropil, weakly stained plexuses formed by NADPH-d-positive processes were observed. No such plexuses were found in the central area of the neuropil (Fig. 2B).

In the cerebropleural ganglia, large and medium-sized pyriform or oval neurons with high enzyme activity (0.329-0.884 optical density units) were mainly stained. They occurred separately or in groups of 10-12 cells. Their processes were weakly stained.

In the visceral ganglia, only single neurons were NADPH-d-positive (0.107-0.581 optical density units). In these ganglia, nerve fibers were stained less intensely than in the cerebropleural ganglia.

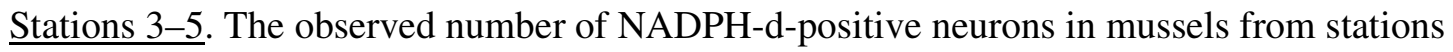
3,4 , and 5 was greater than in mussels from station 1 . The staining intensity, as estimated by eye, was also higher in the former mussels, especially in the dorsomedial portion of the pedal ganglia (Fig. 3A, B). Quantitative estimation of NADPH-d-positive neuron proportion and staining intensity confirmed these observations. However, differences were only significant between stations 1 and 3 (Table 1). In mussels from station 3, the number and staining intensity of NADPH-d- 
positive neurons were maximum. Both parameters were significantly higher in the cerebropleural and pedal compared to visceral ganglia. Obvious visual differences in NADPH-d-positive neuron number and staining intensity between mussels from stations 4 and 5, on the one hand, and control mussels, on the other were not confirmed by statistical analysis. In almost all mussels from stations 3 and 5, pyriform neurons were most heavily stained (1.59-2.02 optical density units). Dark-colored processes arising from the neuron body could be easily traced for long distances. Nerve fibers bore numerous varicosities. In the central and paracortical neuropil areas of all ganglia, processes of NADPH-d-positive neurons formed densely stained plexuses (Fig. 4, 5).

\subsection{NADPH-d activity in mussel ganglia in 3 h after sampling}

Station 1. A $3 \mathrm{~h}$ transportation of mussels in a limited volume of water resulted in a significant (except for two cases) increase in the proportion and staining intensity of NADPH-dpositive neurons in all ganglia (Table 1). Pyriform cells with high enzyme activity (1.84-2.24 optical density units) prevailed among NADPH-d-positive neurons in all ganglia (Fig. 6 A, B). A nerve plexus was densely stained, and numerous varicosities occurred along the entire extents of nerve processes.

Stations 2-5. A $3 \mathrm{~h}$ transportation of mussels from stations $2-5$ resulted in a visible increase in the proportion and staining intensity of NADPH-d-positive neurons in all ganglia (Fig. 7, 8, 9, Table 1). Statistical analysis revealed significant differences in these parameters between freshlysampled and transported mussels, except for the proportion of NADPH-d-positive neurons in the pedal and, in two cases, cerebropleural ganglia. Moreover, some significant differences were revealed between mollusks from different stations. Thus, in mussels from station 3 , the proportion of NADPH-d-positive neurons in the visceral and cerebropleural ganglia was higher than in mussels from reference station 1.

\subsection{NADPH-d activity in mussel ganglia $72 \mathrm{~h}$ after sampling}

In the mollusks maintained in aerated aquaria for $69 \mathrm{~h}$ ( $72 \mathrm{~h}$ including transportation time), only several heavily stained neuronal perikarya were found, with their processes faintly stained (Fig. 10). The number/proportion and staining intensity of NADPH-d-positive neurons in mussels from all stations were relatively low and did not differ significantly from the initial level (Table 1). Nevertheless, the proportion of NADPH-d-positive neurons in the visceral ganglia and staining intensity of neurons in the pedal ganglia were significantly higher in mussels from station 3 than in mollusks from reference station 1 . 


\section{Discussion}

To date, the presence of NADPH-d-positive neurons in the CNS of some bivalve mollusk species, including C. grayanus, has been well established (Dyuizen et al., 1999; Annikova et al., 2000; Kotsyuba \& Kotsyuba, 2002, 2003). In all three ganglion pairs (visceral, cerebropleural, and pedal), NADPH-d-positive neurons of various shapes and sizes may be found lying separately or in groups of up to 35 cells. NADPH-d-positive nerve fibers are also common in the ganglia neuropils, ganglionic commissures, interganglionic connectives, and peripheral nerves arising from ganglia. The staining intensity of nerve fiber varicosities, where NO is presumably actively synthesized, is especially high. NADPH-d-positive peripheral neurons and nerve fibers are found in various parts of the intestinal tract, as well as in female and male gonads in a number of bivalve mollusk species (Annikova et al., 2001; Pimenova et al., 2002; Varaksin et al., 2002; Pimenova, Varaksin, 2006). These findings suggest that NO is involved in regulation of reproduction and digestion in bivalve mollusks.

The present results show that localization and number of NADPH-d-positive neurons in Gray mussels from station 1 (Russky Island; open part of Amursky Bay), as a whole, corresponds to earlier reported data (Annikova et al., 2000). The differences between the present and earlier reported estimations of the percentage of NADPH-d-positive neurons, 0.05 and $0.03 \%$ (visceral ganglia), 0.2 and $0.13 \%$ (cerebropleural ganglia), and 1.4 and $1.6 \%$ (pedal ganglia), respectively, can be accounted for by differences in the physiological state of the mollusks. In the work of Annikova and coauthors (2000), mussels were sampled in November-December, at the early stage of reproductive cycle, while in the present study, they were sampled in August, shortly before mass spawning of this species in Peter the Great Bay in September. It is known that neuronal activity of the bivalves inhabiting temperate waters depends much on the stage of reproductive cycle (Motavkine \& Varaksine, 1989; Reunova et al., 1996).

Furthermore, as was shown above, NADPH-d activity in Gray mussels was considerably influenced by transportation of mollusks and state of the environment. The maximum number and staining intensity of NADPH-d-positive neurons were observed $3 \mathrm{~h}$ after sampling, immediately after mussel delivery to the laboratory. This is probably accounted for by mussel exposure to hypoxia during transportation. In this connection, the data on NADPH-d activity and changes in the morphology of neurons in the chiton Leptochiton assimilis and fresh water bivalve mollusk Nodularia vladivostokensis exposed to acute hypoxia are of a special interest (Kotsyuba, 2003; Kotsyuba \& Kotsyuba, 2003). In these studies, the animals were exposed to hypoxic conditions with an oxygen concentration of about $4 \mathrm{mg} / \mathrm{l}$. In the mollusks exposed to hypoxia for $3 \mathrm{~h}$, NADPH- 
$\mathrm{d}$ activity increased more than thrice. In those exposed to hypoxia for $72 \mathrm{~h}$, the level of enzyme activity significantly dropped remaining, however, higher than in control. As revealed by transmission electron microscopy (TEM), formazan deposits were mainly localized in cytoplasmic granules, and also occurred on the membranes of the nucleus and endoplasmic reticulum and in mitochondria and cytoplasm. Acute $3 \mathrm{~h}$ hypoxic stress induced a sharp increase in the number and size of these granules, as well as an increase in NADPH-d activity in them. After $72 \mathrm{~h}$ of hypoxic exposure, the number and size of granules and NADPH-d activity in them sharply decreased.

Cytoplasmic granules called cytosomes are found in CNS neurons of many terrestrial, fresh water, and marine mollusks (Karnaukhov \& Varton', 1971; Reunova et al., 1996; Kotsyuba, 2003; Kotsyuba \& Kotsyuba, 2003). Using histochemistry and absorption spectral analysis, cytosomes were shown to contain carotinoids, myoglobin, and hemoprotein respiratory enzymes (Karnaukhov \& Varton', 1971). The authors proposed that cytosomes are involved in energy production under hypoxic conditions. The presence of NADPH-d in neuron cytosomes and a sharp increase in the enzyme activity in mollusks exposed to experimental hypoxia allowed us to propose that NO is involved in adaptation of the mollusk CNS to hypoxic conditions (Kotsyuba, 2003; Kotsyuba \& Kotsyuba, 2003). This is confirmed by virtual lack of structural abnormalities in the mollusk neurons even after a $72 \mathrm{~h}$ exposure to hypoxia. The degenerative changes revealed in nerve cells (dilation of perinuclear area and endoplasmic reticulum cisterns, partial destruction of mitochondria) were reversible. Neurons with typical apoptotic morphology only occasionally occurred.

To date, a large amount of data has been accumulated on the role of NO in regulation of mitochondrial respiration. Most of the data were obtained in experiments with isolated mammalian mitochondria (see for review Wink \& Mitchell, 1998; Henry \& Guissani, 1999; Calabrese et al., 2000; Kurhalyuk, 2002). NO involvement into the processes of cell energetics has been shown. Thus, NO reversibly inhibits the key enzyme of respiration chain, cytochromoxidase, acts as an electron acceptor under hypoxic conditions (competing with oxygen), reacts with superoxide $\left(\mathrm{O}_{2}^{-}\right)$ to form a highly reactive compound peroxinitrite $\left(\mathrm{ONOO}^{-}\right)$, which, in turn, reacts with the iron atom in cytochromoxidase heme to irreversibly inhibit the enzyme. It is shown that under hypoxic or anoxic conditions, mitochondria absorb NO, and it reacts directly with cytochromoxidase. Electrons transferred along the electron transport chain (respiration chain) reduce $\mathrm{NO}$ to $\mathrm{NO}_{2}{ }^{-}, \mathrm{NO}_{3}{ }^{-}$, and other products (Borutaite \& Brown, 1996). It is proposed that suppression of cytochromoxidase and other respiration chain enzymes results in disturbances in oxidation processes in mitochondria and in switching from aerobic to anaerobic energy metabolism (glycolysis) (Henry \& Guissani, 1999). Similar mechanisms may also hold for mollusks. The ability of mollusks, in particular, the representatives of the Mytilidae family, to adapt to hypoxic conditions by switching to anaerobic 
metabolism is well known and is being actively investigated (Simpfendorfer et al., 1995; Chen et al., 1997).

NADPH-d activity increase in mollusk neurons under hypoxic stress is probably attributed to the expression of inducible NO-syntase (iNOS). iNOS expression in mammalian neurons induced by a variety of stressors has been shown in many studies (Calingasan et al., 1998; Calabrese et al., 2000). Thus, exposure to acute hypoxia for $6-8 \mathrm{~h}$ resulted in an increase in neuronal iNOS activity, and longer exposure time caused an increase in intracellular glutamic acid concentration and, as a result, NMDA-receptor-mediated neuron death (Schurr et al., 1995). At the same time, some experimental results suggest that iNOS activity increase may be a cell adaptation to stress. The mechanisms of hypoxic tolerance in the mammalian brain have been intensively studied recently. It is known that exposure to moderate hypoxic stress enhances brain tolerance to subsequent severe hypoxia, and NO role in adaptative defence of nerve cells is being debated (Kurhalyuk, 2002). High tolerance of the mollusk CNS to oxygen deficit may be also explained by NO-mediated evolutionary defence mechanisms preventing neuron death.

Another stress factor, whose effect on NADPH-d-activity in C. grayanus CNS is presently shown, is pollution of marine environment. The number and staining intensity of NADPH-dpositive neurons was higher in mussels sampled from stations 2 and 3 (Amursky Bay) and 4 and 5 (Ussuriysky Bay) compared to control mussels (station 1), although the differences were only significant between stations 1 and 3 (Table 1). The differences, though not always significant, were registered in all sampling times. Station 3 is located close to the mouth of highly polluted Vtoraya Rechka River, which is one of the main municipal discharges into Amursky Bay. This area is considered to be the most polluted in the bay. Bottom sediments in this area consist mainly of silt and are characterized by a high content of heavy metals and DDT (Shulkin \& Kavun, 1995; Tkalin, 1996; Tkalin et al., 1997, 1998). In August 2004, the average concentrations of $\mathrm{Fe}, \mathrm{Zn}, \mathrm{Cu}$, and $\mathrm{Pb}$ in fine fraction (particle size $<100 \mu \mathrm{m}$ ) of sediments from station 3 were $33 \pm 0.6 \mathrm{mg} / \mathrm{g}, 205.3 \pm 5.6$, $63.3 \pm 4.7$, and $17.3 \pm 1.5 \mu \mathrm{g} / \mathrm{g}$ of dry weight, respectively, which is $2.1,4.3,5.8$ and 4.3 times higher, respectively, than in sediments from station 1 (Table 2). In the sediments from station 3, the highest concentrations of nickel, oil hydrocarbons and $\sum$ DDTs (total contents of DDT and its derivatives DDD and DDE) were also registered.

Heavy metal concentrations in soft tissues of $C$. grayanus inhabiting this area have been reported to be 2-4 times higher than in the mollusks from the open, relatively clean area of Peter the Great Bay (Shulkin, Kavun, 1995; Shulkin et al., 2002). Recent study conducted as a part of the Asia-Pacific mussel watch program to assess the levels of organochlorine compounds in coastal waters of Asian developing countries has revealed high concentrations of polychlorinated biphenyls (56-70 ng/g wet weight, $3200 \mathrm{ng} / \mathrm{g}$ lipid) in mussels collected in the area close to station 3 
(Monirith et al., 2003). Level of DDTs in mussels was relatively low (11-14 ng/g wet weight), but the percentage of $p, p^{\prime}$-DDT was high up to $50 \%$. We also found high proportions of DDT in the sediments from stations 2 and 3 (64 and 53\%, respectively) in 2004 (M.A. Vaschenko and P.M. Zhadan unpubl. data). These findings denote the recent usage of technical DDT (Monirith et al., 2003).

We propose that higher number of NADPH-d-positive neurons and greater enzyme activity in mussels from stations 2 and 3 in Amursky Bay and 4 and 5 in Ussuriysky Bay are caused by environmental pollution. The same dates of sampling (the second decade of August) and depth (3-4 $\mathrm{m}$ ), the lack of sea water freshening due to dry summer of 2003, and similar temperature values give us additional assurance.

Unfortunately, the data on pollutant content in bottom sediments at all stations are not sufficient. Based on the environmental monitoring data for Peter the Great Bay, it has been accepted that the coastal zone of Amursky Bay is polluted to a greater extent than that of Ussuriysky Bay (see for reviews Vaschenko, 2000; Vaschenko, Pitruk, 2001). As was shown by Shulkin et al. (2003), only localities adjacent to the municipal dump along the west coast of Ussuriyskiy Bay are heavily contaminated by $\mathrm{Zn}, \mathrm{Cu}, \mathrm{Pb}, \mathrm{Ni}$, and $\mathrm{Cd}$. Concentrations of these metals in the sediments from the station nearest to the dump are extremely high, 5736, 3515, 3222, 362, and $27.2 \mu \mathrm{g} / \mathrm{g}$ of dry weight, respectively. The sediments at stations 4 and 5 located far from this source of pollution (14 km southwards and $22 \mathrm{~km}$ northwards, respectively) are not contaminated by heavy metals (see Table 2). However, slightly elevated concentrations of $\mathrm{Zn}, \mathrm{Cu}$ and $\mathrm{Pb}$ in the soft tissues of the mussel C. grayanus from stations 4 and 5, and rather high concentrations of Zn (1683 $\mu \mathrm{g} / \mathrm{g}$ of dry weight) and $\mathrm{Cu}(250 \mu \mathrm{g} / \mathrm{g}$ of dry weight $)$ in the oyster Crassostrea gigas from station 5 have been registered (Shulkin et al., 2003).

It should be noted that heavy metals represent only a part $(<1 \%)$ of a complex mixture of contaminants discharged into the coastal zone around Vladivostok. According to the expert estimates, a portion of organic matter accounts for one third of total waste mass (Tkalin et al., 1993). In the present study, we showed an increase (while insignificant) in both the number of NADPH-d-positive neurons and NADPH-d-activity in mussels from stations 4 (Tikhaya Bay receiving almost untreated municipal wastes) and 5 (Lazurnaya Bay, a municipal beach, which is under considerable recreational disturbance in the summer time). These results suggest that animals in these areas are also exposed to environmental stresses related to water pollution and/or oxygen deficiency. It is well known that water pollution by organic matter, whose oxidation requires oxygen, often results in an oxygen deficit in bottom water layer (Gray et al., 2002).

There are few papers dealing with the effect of pollutants on NO-synthase activity and/or NO production in animals. Kergosien \& Rice (1998) showed that tributyltinoxide (TBTO) (in a 
dose up to $3.0 \mu \mathrm{M} / \mathrm{kg}$ of body weight), but not tributyltinchloride (TBTCl), induced a reversible increase in NO production in mouse macrophages. Smith and coauthors (2000) showed that relatively low TBTO concentrations $(0.001-0.01 \mathrm{mg} / \mathrm{l})$ induced an increase in NO production in hemocytes of the mussel Mytilus edulis, while high concentrations of the toxicant $(0.1 \mathrm{mg} / \mathrm{l})$ significantly inhibited NO production. The authors believe that NO production rate can be used as a highly sensitive indicator of stress reaction of mollusks to environmental changes. In the present study, we showed for the first time an increase in NADPH-d-activity in the CNS of the Gray mussel C. grayanus from chronically polluted environment. These results suggest that NO is involved in adaptation of mollusk neurons to environmental changes.

NO functions in mollusk CNS have been poorly studied. It is known that NO is involved in a variety of functions, both normal (neuromodulation, neurotransmission) and pathological (degeneration, inflammation), in the mammalian brain (see for review Calabrase et al., 2000). It is well established that formation of NO reactive derivatives, such as peroxinitrite, plays an important role in pathological processes in brain. Excessive NO production in the CNS of mollusks inhabiting polluted environments can also produce cytotoxic effects. The light microscopy approach used for the present study did not allow us to reveal any changes in neuron structure in Gray mussels sampled in polluted areas. To reveal these changes, further research using TEM is needed.

\section{Conclusion}

The present study demonstrated that Gray mussel C. grayanus from heavily polluted area of Amursky Bay (Peter the Great Bay, Sea of Japan) exhibited significant increase in the number of NADPH-d positive neurons in the CNS ganglia and in cytochemically measured activity of NADPH-dependent diaphorase, a histochemical marker for nitric oxide synthase, in the neurons. It is tempting to suggest that both parameters may be used as indicators of contaminant exposure in mussels. In this connection, it should be mentioned that there are examples of successful application of cytochemically measured activity of other NADPH-dependent enzymes, DT-diaphorse (quinone oxydoreductase, EC 1.6.99.2) and NADPH-ferrihemoprotein reductase (EC 1.6.2.4), in mussel digestive cells as pollution indicators in natural populations of Mytilus edulis (Krishnakumar et al., 1995). These enzymes are involved in biotransformation of xenobiotics in the digestive gland. However, as was shown in our present and previous studies (Kotsyuba \& Kotsyuba, 2003), other environmental factors such as low oxygen content may also cause changes in activity of NADPHdependent diaphorase involved in NO production in mussel CNS. These changes should be therefore cautiously interpreted. Further study is needed to assess the influence of both abiotic (temperature, salinity, oxygen content) and biotic (reproductive cycle) factors on the responses of 
putative NO-ergic neurons in mussel CNS, and to discriminate between the natural and pollutionrelated effects.

\section{Acknoledgements}

The study was supported by Far East Branch of the Russian Academy of Sciences (grants No 06-1-П 16-057, 06-III-A-06-158, 06-III-A-06-163), and by the Russian Foundation for Basic Research-FEB RAS (grant No 06-04-96034).

\section{References}

Afanasyev, A.A., Kotsyuba, A.E., \& Chertok, B.M. (2002). The system Allegro-MC for automatic analysis of images of micro- and macrostructures. Tihookeansky Meditsinsky Zhurnal (Pacific Medicine Journal), 3, 65-68. (In Russian).

Alderton, W.K., Cooper, C.E., \& Knowles, R.G. (2001). Nitric oxide synthases: structure, function and inhibition. Biochemical Journal, Part 3, 357, 593-615.

Aley, K.O., McCarter, G., \& Levine, J.D. (1998). Nitric oxide signaling in pain and nociceptor sensitization in the rat. The Journal of Neuroscience, 18, 7008-7014.

Annikova, L.V., Pimenova, E.A., Dyuizen, I.V., \& Varaksin, A.A. (2000). Localization of NO-ergic elements in the central nervous system of the bivalve mollusc Crenomytilus grayanus. Journal of Evolutionary Biochemistry and Physiology, 36, 588-594.

Annikova, L.V., Dyuizen, I.V., Paltseva, Y.N., \& Varaksin, A.A. (2001). Putative nitric oxide synthase containing nervous elements in male and female gonads of some marine bivalve mollusks revealed by NADPH-diaphorase histochemistry. Invertebrate Reproduction and Development, 40, 69-77.

$\mathrm{Au}$, D.W.T. (2004). The application of histo-cytopathological biomarkers in marine pollution monitoring: a review. Marine Pollution Bulletin, 48, 813-834.

Bayne, B.L. (ed). (1976). Marine mussels: their ecology and physiology. Cambridge: Cambridge University Press.

Bayne, B.L. (1985). Ecological consequences of stress. In B.L. Bayne, D.A. Brown, K. Burns, D.R. Dixon, A. Ivanovici, D.R. Livingstone, D.M. Lowe, M.N. Moore, A.R.D. Stebbing \& J. Widdows (Eds.), The effects of stress and pollution on marine animals (pp. 141-155). New York: Praeger. 
Bayne, B. L., Moore, M. N., Widdows, J., Livingstone, D. R. \& Salkeld, P. (1979). Measurement of the responses of individuals to environmental stress and pollution. Philosophical Transactions of the Royal Society of London, B286, 563-581.

Belan, T.A., Tkalin, A.V., \& Lishavskaya, T.S. (2003). The present status of bottom ecosystems of Peter the Great Bay (the Sea of Japan). Pacific Oceanography (Vladivostok, Russia), 1, 158167.

Berger, V.J., Kharasova, A.D. (1997). Mechanisms of salinity adaptations in marine molluscs. Hydrobiologia, 355, 115-126.

Borutaite, V., \& Brown, G.C. (1996). Rapid reduction of nitric oxid by mitochondria, and reversible inhibition of mitochondrial respiration by nitric oxide. Biochemical Journal, 315, 295-299.

Bredt, D.S., Glatt, C.E., Hwang, P.M., Dawson, T.M., \& Snyder, S.H. (1991). Nitric oxide syntase protein and mRNA are discretely localized in neuronal populations of the mammalian CNS together with NADPH-diaphorase. Neuron, 7, 615-624.

Cajaraville, M.P., Bebianno, M.J., Blasco, J., Porte, C., Sarasquete, C., \& Viarengo, A. (2000). The use of biomarkers to assess the impact of pollution in coastal environments of the Iberian Peninsula: a practical approach. Science of the Total Environment, 247, 295-311.

Calabrese, V., Bates, T.E., \& Stella, A.M.G. (2000). NO synthase and NO-dependent signal pathways in brain aging and neurodegenerative disorders: the role of oxidant/antioxidant balance. Neurochemical Research, 25, 1315-1341.

Calingasan, N.Y., Park, L.C.H., Calo, L.L., Trifiletti, R.R., Gandy, S.E., \& Gibson, G.E. (1998). Induction of nitric oxide synthase and microglial responses precede selective cell death induced by chronic impairment of oxidative metabolism. American Journal of Pathology, $153,599-610$.

Chen, L., Heath, A.G., \& Neves, R.J. (1997). Oxygen consumption and anaerobic metabolite changes of freshwater mussels (Unionidae) from different habitats during declining dissolved oxygen and air exposure. Journal of Shellfish Research, 16, 343-352.

Colasanti, M., \& Venturini, G. Nitric oxide in invertebrates. (1998). Molecular Neurobiology, 17, $157-174$.

Cozzi, B., Massa, R., \& Panzica, G.C. (1997) The NADPH-diaphorase-containing system in the brain of the budgerigar (Melopsittacus undulatus). Cell and Tissue Research, 287, 101-112.

Dawson, T.M., Bredt, D.S., Fotuhi, M.H., Wang, P.M., \& Snyder, S.H. (1991). Nitric oxide synthase and neuronal NADPH-diaphorase are identical in brain and peripheral tissues. Proceedings of the National Academy of Sciences of the United States of America, 88, 77977801. 
Dyuizen, I.V., Annikova, L.V., \& Motavkin, P.A. (1999). NO-synthase localization in the central nervous system of the bivalve mollusks Mizuhopecten yessoensis and Modiolus kurilensis. Russian Journal of Marine Biology, 25, 277-279.

Garthwaite, J. (1991). Glutamat, nitric oxide and cell-cell signalling in the nervous system. Trends in Neurosciences, 14, 60-67.

Giovine, M., Pozzolini, M., Fayre, A., Bavestrello, G., Cerrano, C., Ottaviani, F., Chiarantini, L., Cerasi, A., Cangiotti, M., Zocchi, E., Scarfi, S., Sara, M., \& Benattitt, U. (2001). Heat stressactivated, calcium-dependent nitric oxide synthase in sponges. Nitric Oxide-Biology and Chemistry, 5, 427-431.

Gray, S.G., Wu, R.S., \& Or, Y.Y. (2002). Effects of hypoxia and organic enrichment on the coastal marine environment. Marine Ecology - Progress Series, 238, 249-279.

Green, D.J., Maiorana, A., O’Driscoll, G., \& Taylor, R. (2004). Effect of exercise training on endothelium-derived nitric oxide function in humans. Journal of Physiology, 561, 1-25.

Halpin, P.M., Menge, B.A., \& Hoffmann, G.E. (2004). Experimental demonstration of plasticity in the heat shock response of the intertidal mussel Mytilus californianus. Marine Ecology Progress Series, 276, 137-145.

Han, H.S., Qiao, Y., Karabiyikoglu, M., Giffard, R.G., \& Yenari, M.A. (2002). Influence of mild hypothermia on inducible nitric oxide synthase expression and reactive nitrogen production in experimental stroke and inflammation. The Journal of Neuroscience, 22, 3921-3928.

Henry, Y., \& Guissani, A. (1999). Interactions of nitric oxide with hemoproteins: roles of nitric oxide in mitochondria. Cellular and Molecular Life Sciences, 55, 1003-1014.

Hope, B.T., \& Vinsent, S.R. (1989). Histochemical characterization of neuronal NADPHdiaphorase. Neurochemistry and Cytochemistry, 37, 653-661.

Hope, B.T., Michael, G.I., Knigge, K.M., \& Vinsent, S.R. (1991). Neuronal NADPH-diaphorase is a nitric oxide syntase. Proceedings of the National Academy of Sciences (USA), 88, 28112814.

Karnaukhov, V.N., \& Varton', S.S. (1971). The ultrastructure of carotenoid-bearing granules in the neurons of Lymnaea stagnalis. Tsitologiya (Cytology), 13, 1088-1093 (In Russian).

Kergosien, D.H., \& Rice, C.D. (1998). Macrophage secretary function is enhanced by low doses of tributyltin-oxide (TBTO), but not tributyltin-chloride (TBTCl). Archive of Environmental Contamination and Toxicology, 34, 223-228.

Kotsyuba, E.P. (2003). Localization of NADPH diaphorase in the central nervous system of the chiton Leptochiton assimilis in the norm and after hypoxia. Tsitologiya (Cytology), 45, 1234-1238. (In Russian). 
Kotsyuba, E.P., \& Kotsyuba, A.E. (2002). Localisation of NADPH diaphorase in the central nervous system of the bivalve mollusc Cristaria tuberculata. Tsitologiya (Cytology), 44, 925-929. (In Russian).

Kotsyuba, E.P., \& Kotsyuba, A.E. (2003). NO-synthase in the central nervous system of freshwater bivalve mollusc Nodularia vladivostokensis in norm and in hypoxia. Journal of Evolutionary Biochemistry and Physiology, 39, 179-183.

Krishnakumar, P.K., Casillas, E., \& Varanasi, U. (1995). Effects of chemical contaminants on the health of Mytilus edulis from Puget Sound, Washington. II. Cytochemical detection of subcellular changes in digestive cells. Marine Ecology - Progress Series, 124, 251-259.

Kurhalyuk, N.N. (2002). Nitric oxide as adaptive protection factor at hypoxia. Uspehi Fisiologicheskih nauk (Progress in Physiological Sciences), 33: 65-79. (In Russian).

Lee, C.-C., Lee, Y.-Y., Chang, C.-K., \& Lin, M.-T. (2005). Selective inhibition of inducible nitric oxide synthase attenuates renal ishemia and damage in experimental heatstroke. Journal of Pharmacological Sciences, 99, 68-76.

Livigstone, D.R., Chipman, J.K., Lowe, D.M., Minier, C., Mitchelmore, C.L., Moore, M.N., Peters, L.D., \& Pipe, R.K. (2000). Development of biomarkers to detect the effects of organic pollution on aquatic invertebrates: recent molecular, genotoxic, cellular and immunological studies on the common mussel (Mytilus edulis L.) and other mytilids. International Journal of Environment and Pollution, 13, 56-91.

Malyshev, I.Yu., \& Manukhina, E.B. (1998). Stress, adaptation, and nitric oxide. Biochemistry (Moscow), 63, 840-853.

Manukhina, E.B., Mashina, S.Yu., Smirin, B.V., Lyamina, N.P., Senchikhin, V.N., Vanin, A.F., \& Malyshev, I.Yu. (2000). Role of nitric oxide in adaptation to hypoxia and adaptive defense. Physiological Research, 49, 89-97.

Masood, A., Banerji, B., Vijayan, V.K., \& Ray, A. (2004). Pharmacological and biochemical studies on the possible role of nitric oxide in stress adaptation in rats. European Journal of Pharmacology, 493, 111-115.

Mayer, B., \& Hemmens, B. (1997). Biosynthesis and action of nitric oxide in mammalian cells. Trends in Biochemical Sciences, 22, 477-481.

Moles, A., \& Hale, N. (2003). Use of physiological responses in Mytilus trossulus as integrative bioindicators of sewage pollution. Marine Pollution Bulletin, 46, 954-958.

Moncada, S., Palmer, R.M.J., \& Higgs, E.A. (1991). Nitric oxide: Physiology, pathophysiology, and pharmacology. Pharmacological Reviews, 43, 109-142.

Monirith, I., Ueno, D., Takahashi, S., Nakata, H., Sudaryanto, A., Subramanian, A., Karuppiah, S., Ismail, A., Muchtar, M., Zheng, J., Richardson, B.J., Prudente, M., Hue, N.D., Tana, T.S., 
Tkalin, A.V., \& Tanabe, S. (2003). Asia-Pacific mussel watch: monitoring contamination of persistent organochlorine compounds in coastal waters of Asian countries. Marine Pollution Bulletin,46, 281-300.

Moore, M.N. (1985). Cellular responses to pollution. Marine Pollution Bulletin, 16, 134-139.

Moore, M.N., Allen, J.I., \& McVeigh, A. (2006). Environmental prognostics: an integrated model supporting lysosomal stress responses as predictive biomarkers of animal health status. Marine Environmental Research, 62, 278-304.

Moroz, L.L., \& Gillette, R. (1995). From Polyplacophora to Cephalopoda: comparative analysis of nitric oxide signalling systems in Mollusca. Acta Biologica Hungarica, 46, 169-182.

Moroz, L.L., Chen, D., Gillette, M.U., \& Gillette, R. (1996) Nitric oxide synthase activity in the molluscan CNS. Journal of Neurochemistry, 66, 873876.

Motavkine, P.A., \& Varaksine, A.A. (1989). Le reproduction chez lez mollusques bivalves role du systeme nervaux et regulation. Rapports Scientifiques et Techniques (No. 10, pp. 1-250). Brest (France): IFREMER.

Narbonne, J.F., Aarab, N., Clerandeau, C., Daubeze, M., Narbonne, J., Champeau, O., \& Garrigues, P. (2005). Scale of classification based on biochemical markers in mussels: application to pollution monitoring in Mediterranean coasts and temporal trends. Biomarkers, 10, 58-71.

Nathan, C. (1992). Nitric oxide as a secretory product of mammalian cells. FASEB Journal, 6, 3051-3064.

Nathan, C., \& Xie, Q.W. (1994). Nitric-oxide synthases - roles, tolls, and controls. Cell, 78, 915918.

Newcomb, J.M., \& Watsan, W.H. (2001). Identifiable nitrergic neurons in the central nervous system of the nudibranch Melibe leonina localized with NADPH-diaphorase histochemistry and nitric oxide synthase immunoreactivity. Journal of Comparative Neurology, 437, 70-78.

Palumbo, A. (2005). Nitric oxide in marine invertebrates: A comparative perspective. Comparative Biochemistry and Physiology, 142A, 241-248.

Pimenova, E.A., Khlopova, A.V., \& Varaksin, A.A. (2002). Nitroxidergic cells in the intestine of the bivalve mollusk Modiolus kurilensis. Russian Journal of Marine Biology, 28, 107-112.

Pimenova, E.A., \& Varaksin, A.A. (2006). Putative nitroxidergic cells in the digestive system of some mytilids (Mollusca: Bivalvia: Mytilidae) revealed by NADPH-diaphorase histochemistry. Malacologia, 49, 61-78.

Reunova, O.V., Kalinina, G.G., \& Motavkin, P.A. (1996). Neurosecretory activity and dynamics of lipid content in the CNS neurons of the bivalve mollusk, Gray mussel. Morfologiya (Morphology), 110, 75-82 (In Russian). 
Schurr, A., Payne, R.S., Haine, M.F., \& Rigor, B.M. (1995). Hypoxia, excitoxicity and neuroprotection in the hippocampal slice preparation. Journal of Neuroscience Methods, 59, $129-138$.

Shirakawa, T., Mitome, M., Kikuiri, T., Nakamura, W., Oshima, S., Hasegawa, T., Shindoh, M., \& Oguchi, H. (2004). Immobilization induces acute nitric oxide production in the rat hypothalamus: a role of ionotropic glutamate receptors in the paraventricular nucleus. Endocrinology, 145, 3603-3607.

Shulkin, V.M. \& Kavun, V.Ya. (1995). The use of marine bivalves in heavy metal monitoring near Vladivostok, Russia. Marine Pollution Bulletin, 31, 330-333.

Shulkin, V.M., Kavun, V.Ya., Tkalin, A.V., \& Presley, B.J. (2002). The effect of metal concentration in bottom sediments on the accumulation of metals by the mytilids Crenomytilus grayanus and Modiolus kurilensis. Russian Journal of Marine Biology, 28, $43-51$.

Shulkin, V.M., Presley, B.J., \& Kavun, V.Ya. (2003). Metal concentrations in mussel Crenomytilus grayanus and oyster Crassostrea gigas in relation to contamination of ambient sediments. Environment International, 29, 493- 502.

Simpfendorfer, R.W., Vial, M.V., Lopez, D.A., Verdala, M., \& Gonzalez, M.L. (1995). Relationship between the aerobic and anaerobic metabolic capacities and the vertical distribution of three intertidal sessile invertebrates: Jehlius cirratus (Darwin) (Cirripedia), Perumytilus purpuratus (Lamark) (Bivalvia) and Mytilus chilensis (Hupe) (Bivalvia). Comparative Biochemistry and Physiology B: Biochemistry Molecular Biology, 111, 615623.

Smith, K.L., Galloway, T.S., \& Depledge, M.H. (2000). Neuro-endocrine biomarkers of populationinduced stress in marine invertebrates. The Science of Total Environment, 262, 185-190.

Stefano, G.B., \& Ottaviani, E. (2002). The biochemical substrate of nitric oxide signaling is present in primitive non-cognitive organisms. Brain Research, 924, 82-89.

Stuehr, D.J. (1999). Mammalian nitric oxide synthases. Biochimica et Biophysica ActaBioenergetics, 1411, 217-230.

Sukhotin A.A., \& Portner H.O. (1999). Habitat as a factor involved in the physiological response to environmental anaerobiosis of White Sea Mytilus edulis. Marine Ecology-Progress Series, $184,149-160$.

Tkalin, A.V. (1996). Chlorinated hydrocarbons in coastal bottom sediments of the Japan Sea. Environmental Pollution, 91, 183-185.

Tkalin, A.V., Belan, T.A., \& Shapovalov, E.N. (1993).The state of the marine environment near Vladivostok, Russia. Marine Pollution Bulletin, 26, 418-422. 
Tkalin, A.V., Presley, B.J., \& Booth, P.N. (1996). Spatial and temporal variations of trace metals in bottom sediments of Peter the Great Bay, the Sea of Japan. Environmental Pollution, 92, 73-78.

Tkalin, A.V., Lishavskaya, T.S., \& Hills, J.W. (1997). Organochlorine pesticides in mussels and bottom sediments from Peter the Great Bay near Vladivostok. Ocean Research, 19, 115119.

Tkalin, A.V., Lishavskaya, T.S., \& Shulkin, V.M. (1998). Radionuclides and trace metals in mussels and bottom sediments around Vladivostok, Russia. Marine Pollution Bulletin, 36, $551-554$.

Toda, N., \& Ayajiki, K. (2006). Phylogenesis of constitutively formed nitric oxide in nonmammals. Reviews of Physioljgy, Biochemistry and Pharmacology, 138, 31-80.

Varaksin, A.A., Pimenova, E.A., Varaksina, G.S., \& Frolova, L.T. (2002). Localization of NADPHdiaphorase-positive elements in the intestine of the mussel Crenomytilus grayanus. Malacologia, 44, 135-143.

Vaschenko, M.A. (2000). Pollution in Peter the Great Bay, Sea of Japan, and its biological consequences. Russian Journal of Marine Biology, 26, 155-166.

Vaschenko, M.A., \& Pitruk, D.L. (2001). Comparative assessment of the condition of the marine environment and biota in various parts of Peter the Great Bay including the Tumen River mouth area. In V.L. Kasyanov, M.A. Vaschenko, D.L. Pitruk (Eds.), The state of environment and biota of the southwestern part of Peter the Great Bay and the Tumen River mouth (vol. 3, pp. 3-18). Vladivostok: Dalnauka.

Vaschenko, M.A., Syasina, I.G., Durkina, V.B., \& Zhadan, P.M. (2003). Contamination of sediments and histological alterations in barfin plaice Pleuronectes pinnifasciatus from Amursky Bay (Peter the Great Bay, East Sea/Sea of Japan). Ocean and Polar Research, 25, $31-40$.

Wink, D.A., \& Mitchell, J.B. (1998). Chemical biology of nitric oxide: insights into regulatory, cytotoxic, and cytoprotective mechanisms of nitric oxide. Free Radical Biology and Medicine, 25, 434-456.

\section{Legends to the figures}

Fig. 1. A schematic map of sampling sites in Peter the Great Bay (Sea of Japan): 1 - Russky Island, 2 - Tokarevsky Cape, 3 -Vtoraya Rechka River, 4 - Tikhaya Bay, 5 - Lazurnaya Bay. 
Fig. 2. Localization of NADPH-diaphorase in the pedal ganglia of freshly sampled Gray mussel Crenomytilus grayanus from station 1: A - dorsomedial area of the pedal ganglia, B - a part of the right pedal ganglion. Fibers in the central area of the neuropil $(\mathrm{N})$ are not stained. Scale bar, 100 $\mu \mathrm{m}$.

Fig. 3. Localization of NADPH-diaphorase in the pedal ganglia of freshly sampled Gray mussel Crenomytilus grayanus from station 3: A - dorsomedial area of the pedal ganglia, B - a part of the right pedal ganglion. Fibers in the central area of the neuropil $(\mathrm{N})$ are intensively stained. Scale bar, $100 \mu \mathrm{m}$.

Fig. 4. Localization of NADPH-diaphorase in the visceral ganglia of freshly sampled Gray mussel Crenomytilus grayanus from station 3. N - neuropil. Scale bar, $100 \mu \mathrm{m}$.

Fig. 5. Localization of NADPH-diaphorase in the dorsolateral area of the cerebropleural ganglia of freshly sampled Gray mussel Crenomytilus grayanus from station 5. Scale bar, $100 \mu \mathrm{m}$.

Fig. 6. Localization of NADPH-diaphorase in the pedal ganglia of the Gray mussel Crenomytilus grayanus from station $13 \mathrm{~h}$ after sampling: A - dorsomedial area of the pedal ganglia, B - a part of the right pedal ganglion. $\mathrm{N}-$ neuropil. Scale bar, $100 \mu \mathrm{m}$.

Fig. 7. Localization of NADPH-diaphorase in the dorsolateral area of the cerebropleural ganglia of the Gray mussel Crenomytilus grayanus from station $53 \mathrm{~h}$ after sampling. $\mathrm{N}$ - neuropil. Scale bar, $100 \mu \mathrm{m}$.

Fig. 8. Localization of NADPH-diaphorase in the ventrolateral area of the cerebropleural ganglia of the Gray mussel Crenomytilus grayanus from station $53 \mathrm{~h}$ after sampling. $\mathrm{N}$ - neuropil. Scale bar, $100 \mu \mathrm{m}$.

Fig. 9. Localization of NADPH-diaphorase in the right pedal ganglion of the Gray mussel Crenomytilus grayanus from station $33 \mathrm{~h}$ after sampling. $\mathrm{N}$ - neuropil. Scale bar, $100 \mu \mathrm{m}$.

Fig. 10. Localization of NADPH-diaphorase in the right pedal ganglion of the Gray mussel Crenomytilus grayanus from station $172 \mathrm{~h}$ after sampling. $\mathrm{N}-$ neuropil. Scale bar, $100 \mu \mathrm{m}$. 
Table 1

Percentage (A) and optical density (B, optical density units) of NADPH-diaphorase positive neurons in the CNS of the Gray mussel Crenomytilus grayanus from different areas of Peter the Great Bay (Sea of Japan)

\begin{tabular}{|c|c|c|c|c|c|c|c|}
\hline \multirow[t]{2}{*}{ Station } & \multirow{2}{*}{$\begin{array}{l}\text { Time after } \\
\text { sampling, } \\
\mathrm{h}\end{array}$} & \multicolumn{2}{|l|}{ Visceral ganglion } & \multicolumn{2}{|c|}{ Cerebropleural ganglion } & \multicolumn{2}{|c|}{ Pedal ganglion } \\
\hline & & A & B & A & B & $\mathrm{A}$ & B \\
\hline \multirow[t]{3}{*}{1} & 0 & $0.05 \pm 0.003$ & $0.123 \pm 0.01$ & $0.2 \pm 0.01$ & $0.196 \pm 0.01$ & $1.4 \pm 0.2$ & $0.398 \pm 0.02$ \\
\hline & 3 & $0.06 \pm 0.001^{b}$ & $0.294 \pm 0.01^{b}$ & $0.24+0.01$ & $0.34 \pm 0.03^{b}$ & $1.65 \pm 0.1$ & $0.84 \pm 0.01^{b}$ \\
\hline & 72 & $0.048 \pm 0.001$ & $0.121 \pm 0.01$ & $0.21 \pm 0.04$ & $0.201 \pm 0.03$ & $1.4 \pm 0.25$ & $0.406 \pm 0.03$ \\
\hline \multirow[t]{2}{*}{2} & 3 & $0.062 \pm 0.002$ & $0.303 \pm 0.02$ & $0.27 \pm 0.02$ & $0.38 \pm 0.05$ & $1.68 \pm 0.1$ & $0.88 \pm 0.1$ \\
\hline & 72 & $0.052 \pm 0.001^{c}$ & $0.129 \pm 0.02^{c}$ & $0.2 \pm 0.01^{b}$ & $0.209 \pm 0.02^{b}$ & $1.50 \pm 0.1$ & $0.417 \pm 0.02^{c}$ \\
\hline \multirow[t]{3}{*}{3} & 0 & $0.058 \pm 0.001$ & $0.143 \pm 0.02$ & $0.26 \pm 0.02 * *$ & $0.262 \pm 0.04$ & $1.62 \pm 0.1$ & $0.598 \pm 0.03 * *$ \\
\hline & 3 & $0.067 \pm 0.001^{b} * *$ & $0.371 \pm 0.04^{b}$ & $0.32 \pm 0.01^{a * *}$ & $0.51 \pm 0.06^{b}$ & $1.79 \pm 0.2$ & $1.04 \pm 0.1^{b}$ \\
\hline & 72 & $0.056 \pm 0.003 *$ & $0.160 \pm 0.01$ & $0.26 \pm 0.02$ & $0.26 \pm 0.01$ & $1.6 \pm 0.1$ & $0.602 \pm 0.05 * *$ \\
\hline \multirow[t]{3}{*}{4} & 0 & $0.055 \pm 0.003$ & $0.128 \pm 0.01$ & $0.23 \pm 0.01 *$ & $0.223 \pm 0.03$ & $1.51 \pm 0.1$ & $0.411 \pm 0.01$ \\
\hline & 3 & $0.065 \pm 0.002^{a}$ & $0.312 \pm 0.04^{b}$ & $0.29 \pm 0.02^{a}$ & $0.420 \pm 0.07^{b}$ & $1.71 \pm 0.1$ & $0.91 \pm 0.1^{b}$ \\
\hline & 72 & $0.050 \pm 0.002$ & $0.129 \pm 0.01$ & $0.23 \pm 0.01$ & $0.240 \pm 0.01$ & $1.50 \pm 0.1$ & $0.50 \pm 0.04$ \\
\hline \multirow[t]{3}{*}{5} & 0 & $0.055 \pm 0.001$ & $0.136 \pm 0.02$ & $0.23 \pm 0.01$ & $0.212 \pm 0.02$ & $1.55 \pm 0.1$ & $0.487 \pm 0.03$ \\
\hline & 3 & $0.064 \pm 0.001^{b}$ & $0.321 \pm 0.01^{b}$ & $0.26 \pm 0.01$ & $0.491 \pm 0.06^{b}$ & $1.75 \pm 0.1$ & $1.02 \pm 0.09^{b}$ \\
\hline & 72 & $0.052 \pm 0.001$ & $0.132 \pm 0.01$ & $0.24 \pm 0.02$ & $0.244 \pm 0.02$ & $1.59 \pm 0.1$ & $0.468 \pm 0.03$ \\
\hline
\end{tabular}

Note. Data are presented as means of 10 mussels ( 7 sections per each ganglion) \pm standard errors. Italic letters indicate significance of differences between the mussels from the same station taken at different time intervals after sampling (compared to freshly sampled mussels): ${ }^{a} P<0.05,{ }^{b} P<0.01$, ${ }^{c} P<0.001$. For station 2, the differences between the mussels taken at 3 and $72 \mathrm{~h}$ after sampling were determined. Asterisks indicate significance of differences between the mussels from stations $2-5$ and station 1 taken at the same time after sampling: $* P<0.05, * * P<0.01$. Bold font denotes the absence of statistically significant differences in NADPH-d activity between the visceral and cerebropleural ganglia $(P>0.05)$. 
Table 2. Average concentrations ( $n=6)$ of oil hydrocarbons $(\mathrm{OH}), \sum \mathrm{DDT}$ (total contents of DDT and its derivatives DDD and DDE) and heavy metals in the sediments from sampling stations $1-5$ in Peter the Great Bay (Sea of Japan)

\begin{tabular}{|c|c|c|c|c|c|c|c|c|c|}
\hline Station & $\begin{array}{c}\mathrm{OH} \\
\mu \mathrm{g} / \mathrm{g} \text { d.w. }\end{array}$ & $\begin{array}{l}\sum \mathrm{DDT} \\
\text { ng/g d.w. }\end{array}$ & $\begin{array}{c}\mathrm{Fe} \\
\mathrm{mg} / \mathrm{g} \text { d.w. }\end{array}$ & $\begin{array}{c}\text { Zn, } \\
\mu \mathrm{g} / \mathrm{g} \text { d.w. }\end{array}$ & $\begin{array}{l}\mathrm{Cu}, \\
\mu \mathrm{g} / \mathrm{d} . \mathrm{w} .\end{array}$ & $\begin{array}{c}\mathrm{Pb} \\
\mu \mathrm{g} / \mathrm{g} \text { d.w. }\end{array}$ & $\begin{array}{c}\mathrm{Ni} \\
\mu \mathrm{g} / \mathrm{g} \text { d.w. }\end{array}$ & $\begin{array}{c}\mathrm{Cd} \\
\mathrm{lg} / \mathrm{g} \text { d.w. }\end{array}$ & Reference \\
\hline 1 & 72 & 1.4 & 15.8 & 47.9 & 11 & 4.1 & 5.9 & $-\infty$ & \multirow{3}{*}{$\begin{array}{l}\text { M.A. Vaschenko and P.M. Zhadan, } \\
\text { unpubl. data } \\
\text { Shulkin et al. } 2003\end{array}$} \\
\hline 2 & 131 & 5.3 & 27.7 & 179 & 52 & 17.3 & 70.3 & - & \\
\hline & - & - & - & 194 & 48 & 84 & 32 & . & \\
\hline \multirow[t]{2}{*}{3} & 273 & 18.5 & 33 & 205.3 & 63.3 & 17.3 & 77.6 & & $\begin{array}{l}\text { M.A. Vaschenko and P.M. Zhadan, } \\
\text { unpubl. data }\end{array}$ \\
\hline & - & - & - & 204 & 42 & 91 & 50 & 0.25 & Shulkin et al., 2003 \\
\hline 4 & - & - & - & 36 & 8.6 & 26.6 & 10.9 & 0.1 & Shulkin et al., 2003 \\
\hline 5 & - & - & - & 41.4 & 4.6 & 18.2 & 14.6 & 0.2 & Shulkin et al., 2003 \\
\hline $\mathrm{Bm}$ & $<100 *$ & - & - & 76 & 15.3 & 18.6 & 6.2 & 0.23 & Shulkin et al., 2003 \\
\hline
\end{tabular}

Note. Stations 2, 3, 4 and 5 of the present work correspond to stations 4, 2, 5 and 16 investigated by in Shulkin et al., 2003 (see Fig. 1).

$\mathrm{Bm}$ - background mud (>80\% particles less than $0.01 \mathrm{~mm}$ ) sampled in the outer part of Amursky Bay (after Shulkin et al., 2003).

* Background concentration of oil hydrocarbons in sediments of Peter the Great Bay is given according to Vaschenko et al., 2003.

- : No data is available. 


\section{ACCEPTED MANUSCRIPT}

23

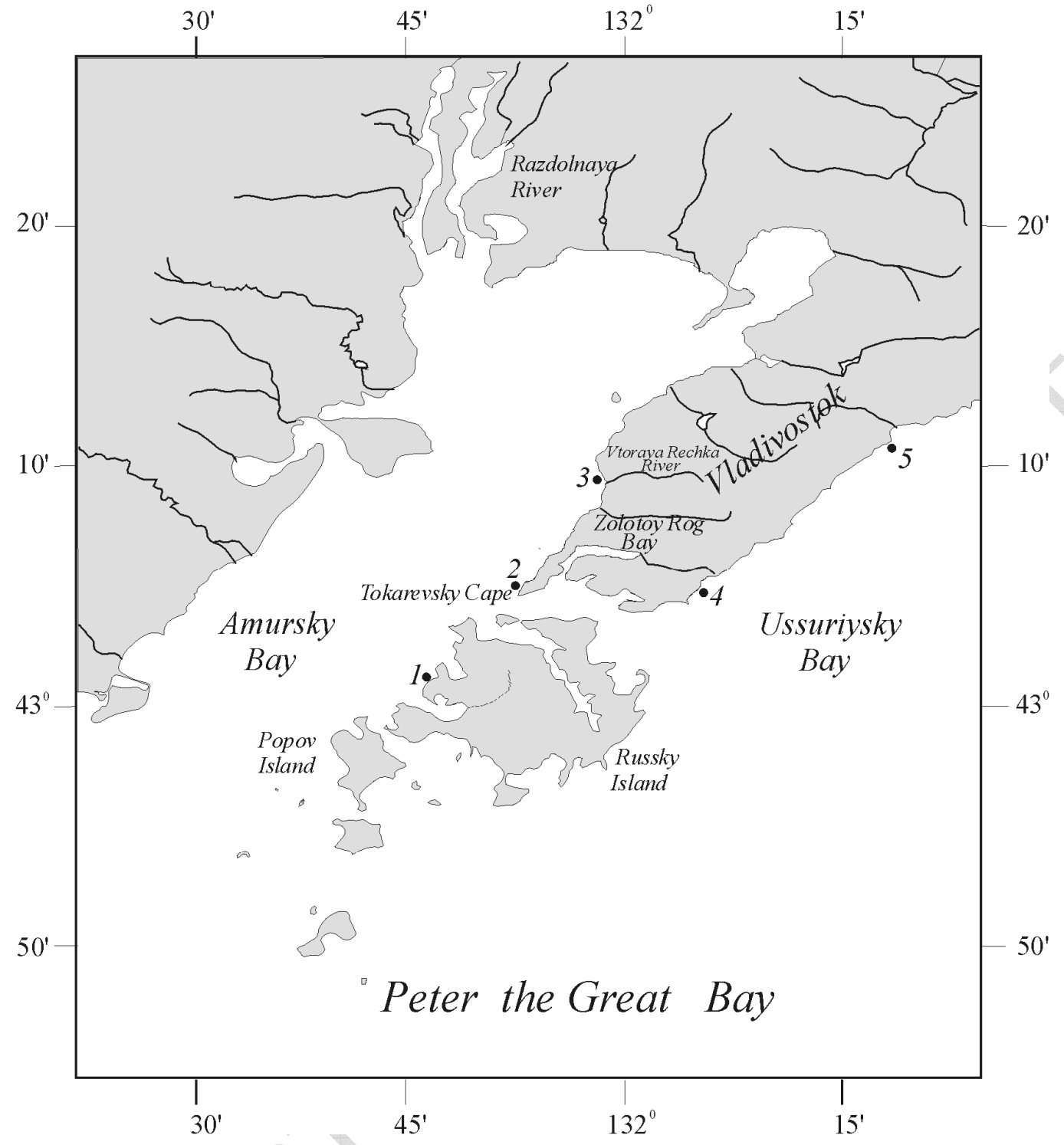

Fig 1 


\section{ACCEPTED MANUSCRIPT}

24
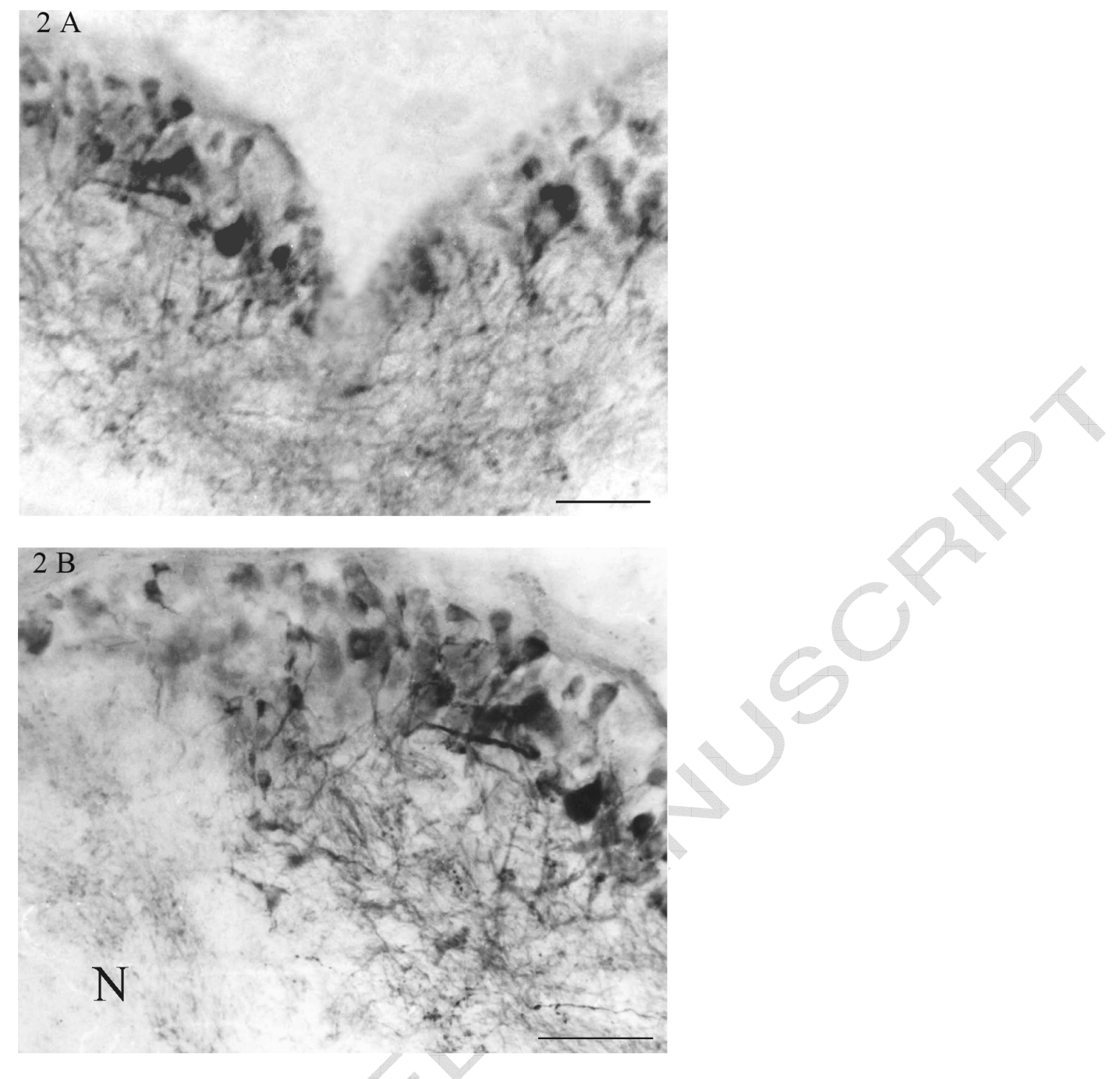

Fig 2 


\section{ACCEPTED MANUSCRIPT}

25
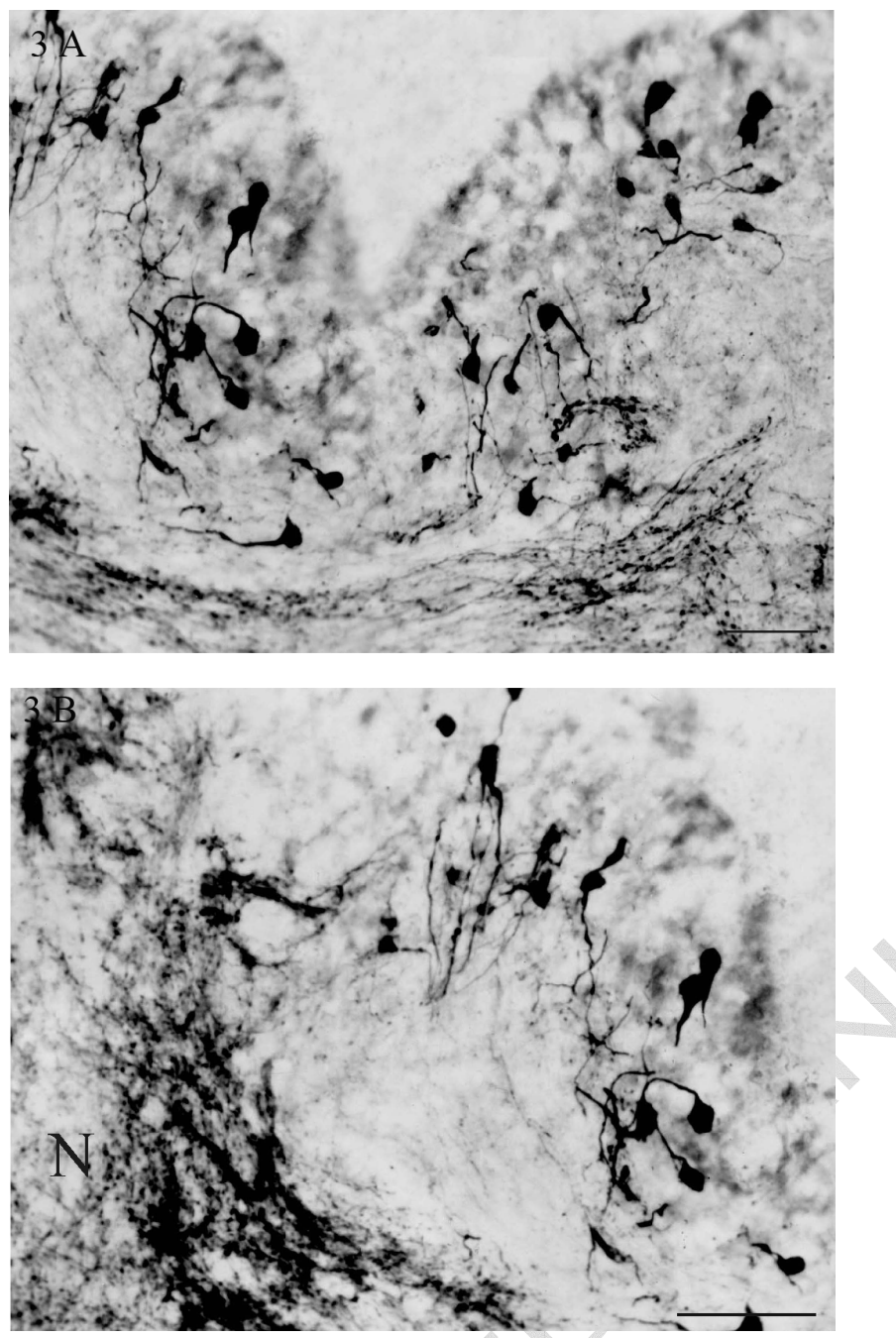

Fig 3 


\section{ACCEPTED MANUSCRIPT}

26

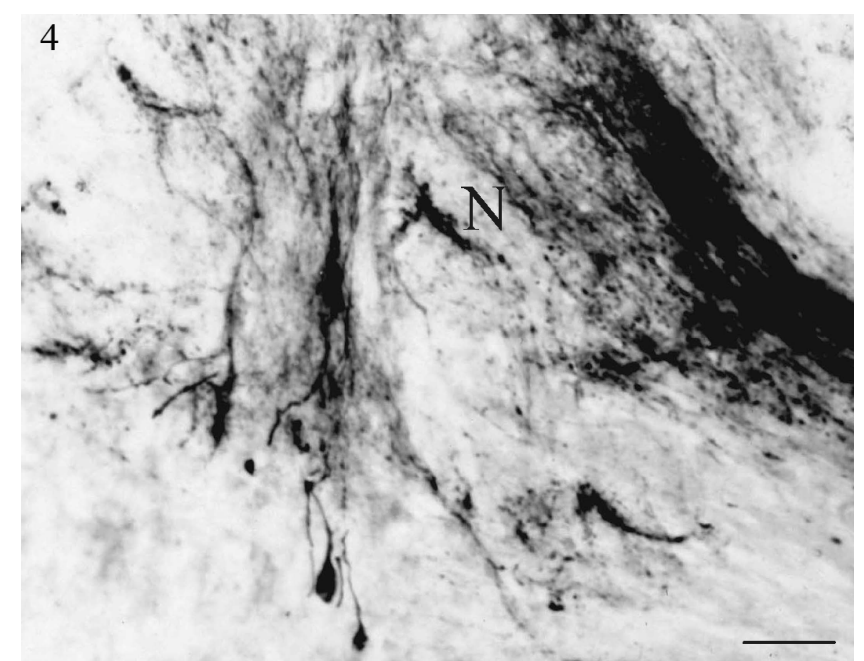

Fig 4

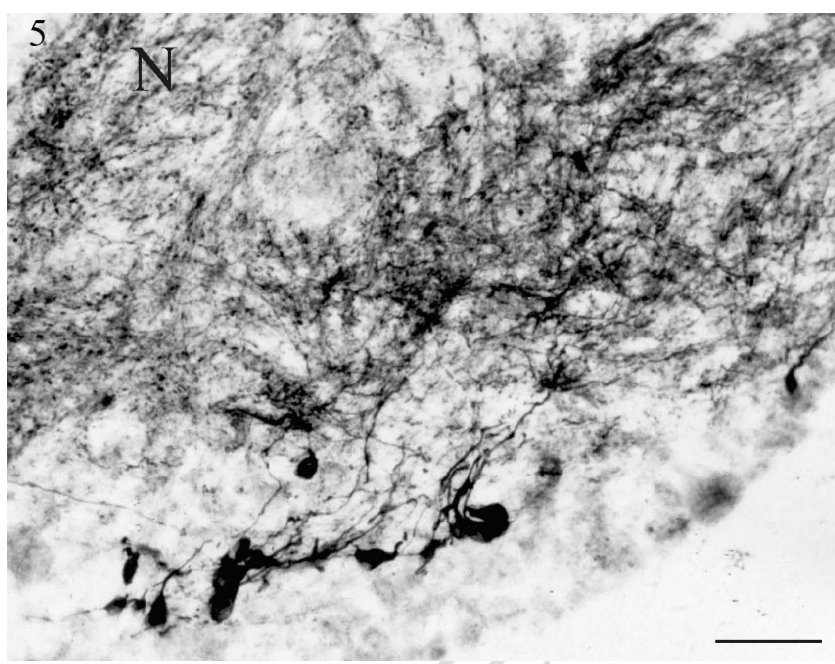

Fig 5 


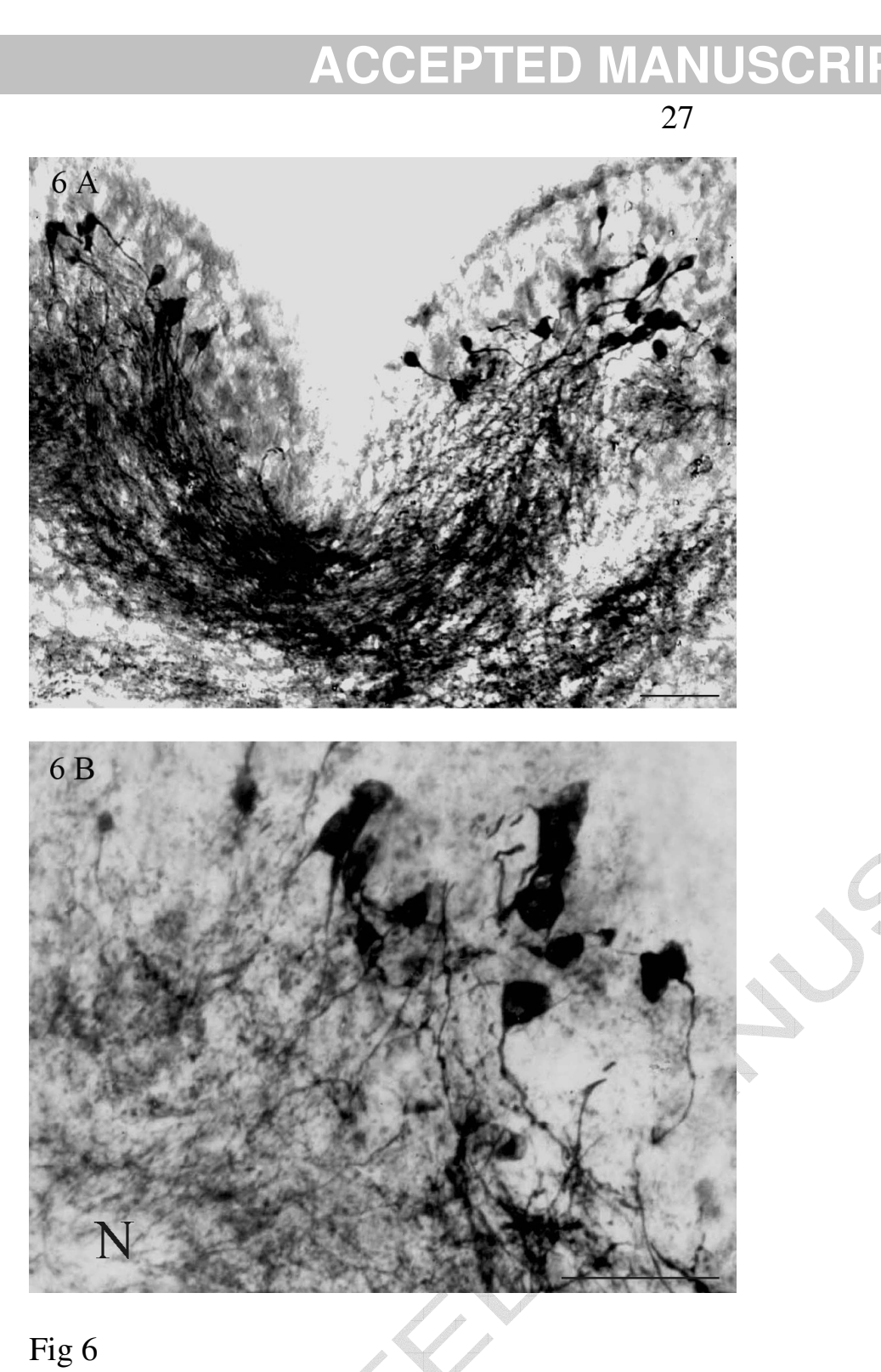




\section{ACCEPTED MANUSCRIPT}

28

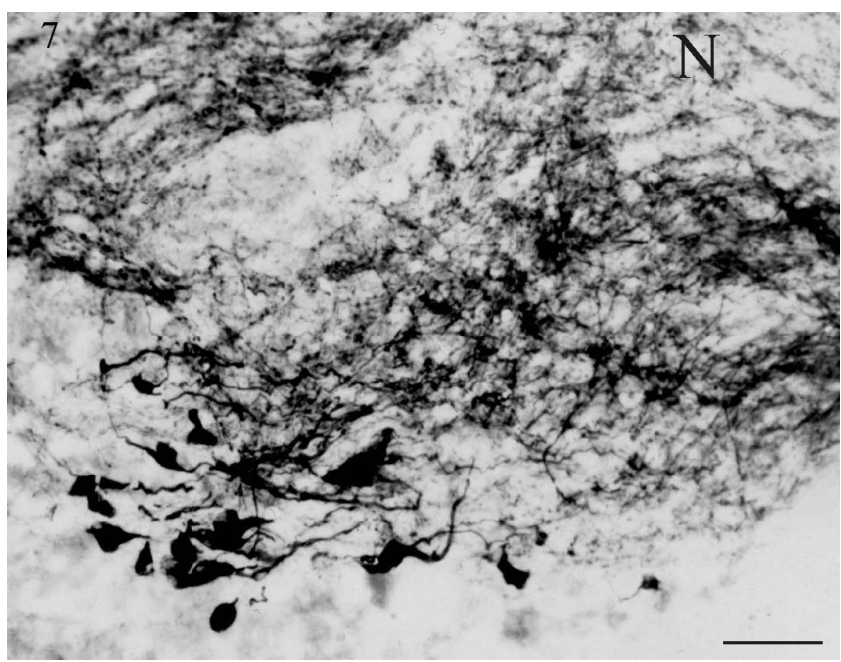

Fig 7

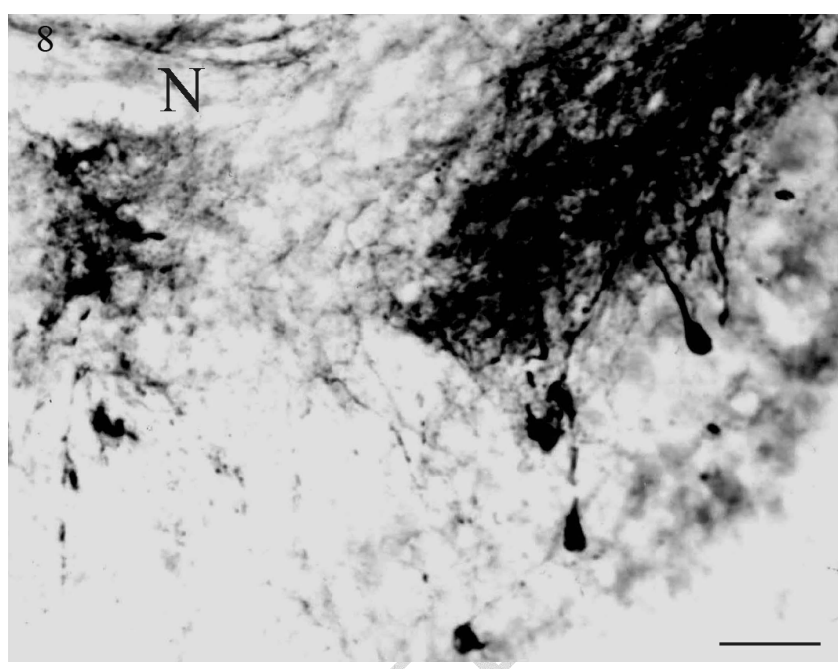

Fig 8 


\section{ACCEPTED MANUSCRIPT}

29

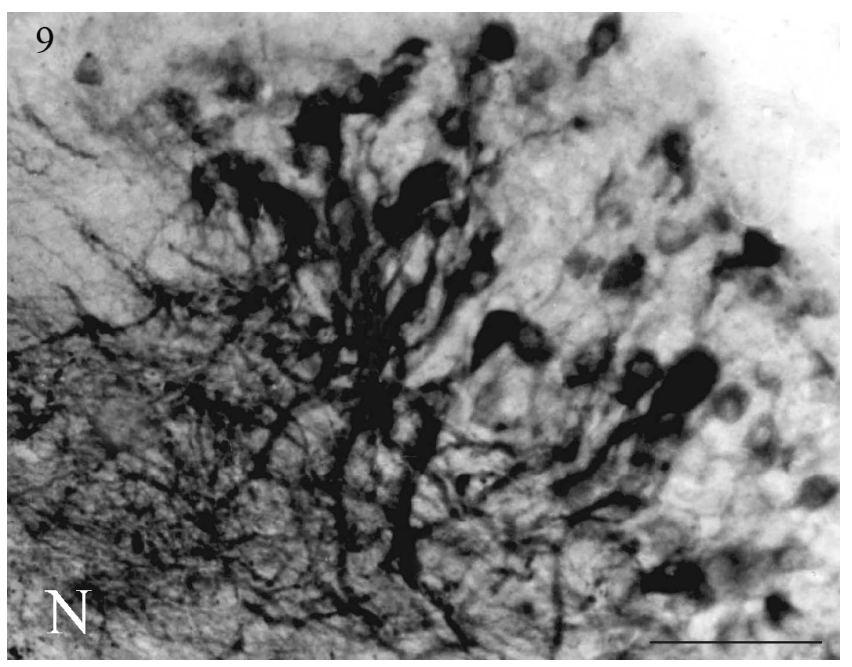

Fig 9

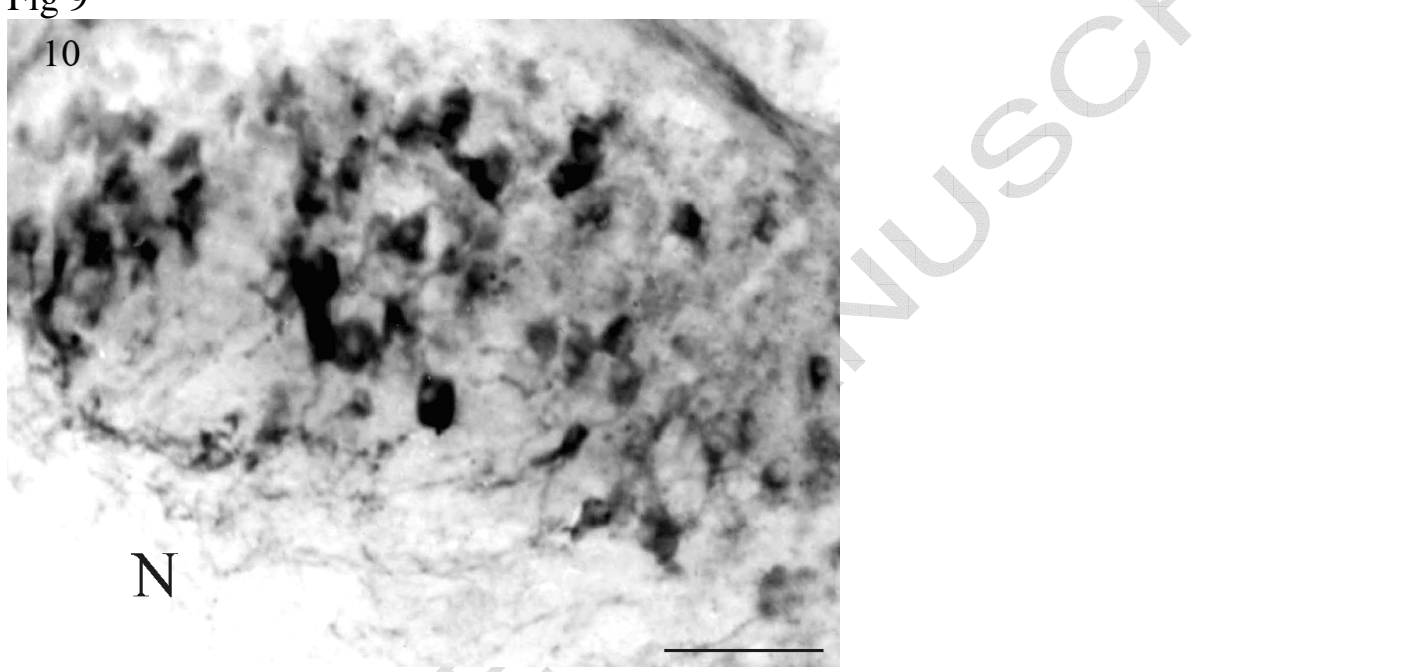

Fig 10 